\title{
HPLC ANALYSIS OF PHENOLIC COMPOUNDS, ANTIOXIDANT AND ANTIMICROBIAL ACTIVITY OF AMORPHA FRUTICOSA L. EXTRACTS
}

\author{
Bianca IVĂNESCU ${ }^{1}$, Cristina LUNGU ${ }^{1 *}$, Laurian VLASE$^{2}$, \\ Adina Catinca GRĂDINARU ${ }^{1}$, Cristina TUCHILUŞ ${ }^{3}$
}

\footnotetext{
${ }^{1}$ Department of Pharmaceutical Botany, Faculty of Pharmacy, "Grigore T. Popa" University of

Medicine and Pharmacy, 16 Universitatii Street, 700115, Iaşi - Romania

${ }^{2}$ Department of Pharmaceutical Technology and Biopharmacy, Faculty of Pharmacy, "Iuliu

Hatieganu" University of Medicine and Pharmacy, 12 Ion Creanga Street, 400010, Cluj-Napoca - Romania

${ }^{3}$ Department of Mycrobiology, Faculty of Pharmacy, "Grigore T. Popa" University of Medicine and Pharmacy, 16 Universitatii Street, 700115, Iaşi - Romania

${ }^{*}$ Corresponding author. E-mail: ape3_c@yahoo.com
}

\begin{abstract}
The present study focuses on the chemical and biological analysis of the ethanolic $70 \% \mathrm{v} / \mathrm{v}$ extracts obtained from Amorpha fruticosa leaves, branches and fruits. The total phenolic content determined by Folin-Ciocalteu method was the highest in leaves extract $(159.5 \mathrm{mg} / \mathrm{g})$. The HPLC-MS analysis indicated the presence of ferulic acid, luteolin and rutoside in all three extracts. The antioxidant activity was tested by the $\mathrm{DPPH}$ method and the results indicated a good scavenging activity $\left(\mathrm{EC}_{50}=18.8 \pm\right.$ $0.2 \mu \mathrm{g} / \mathrm{mL})$ for the fruit extract, followed by leaf extract $\left(\mathrm{EC}_{50}=38.03 \pm 0.75 \mu \mathrm{g} / \mathrm{mL}\right)$ and branch extract $\left(\mathrm{EC}_{50}=221.16 \pm 1.7 \mu \mathrm{g} / \mathrm{mL}\right)$. The antimicrobial activity evaluated by agar disc diffusion method indicated the inhibition of growth for Staphylococcus aureus and Sarcina lutea for all samples.
\end{abstract}

Keywords: Amorpha fruticosa L., antimicrobial, antioxidant, polyphenols.

\section{Introduction}

Amorpha fruticosa L. (indigo bush) is a perennial shrub in the Fabaceae family, order Fabales. It is native to south-western part of North America and it was introduced in Europe as an ornamental plant. The species could potentially be used for livestock forage, biomass energy, reclamation of degraded environments, or as insecticide [DE HAAN \& al. 2006, PAPANASTASIS \& al. 2008]. Amorpha fruticosa is considered invasive in Eastern Romania, because it is a naturalized plant that has capacity to spread over a large area [SÎRBU \& al. 2012].

Indigo bush has been used as a Chinese folk medicine for hypertension, hematomas, and contusions. Some isoflavones, flavanones, and rotenoids along with their biological activities have been reported for this plant [LEE \& al. 2006]. For instance, an isoflavone from Amorpha fruticosa can protect the liver from hepatotoxicity induced by acetaminophen [DIAO \& al. 2009]. Also rotenoids and flavanones have been shown to possess antibacterial activity via neuraminidase inhibition [KIM \& al. 2011].

The immunomodulatory and anticancer activity was also reported for Amorpha fruticosa compounds. For example, a prenylfavanone type of flavonoid, amoradicin, manifests tumour necrosis factor (TNF)-alpha inhibitory action [CHO \& al. 2000] and phenolic constituents of Amorpha fruticosa can inhibit NF-kB activation and related gene 
expression [DAT \& al. 2008]. Some rotenoid glycosides of Amorpha fruticosa have immune activation effects and could be developed into immunomodulatory agents [LEE \& al. 2006].

The fruits contain volatile oil and glycosides of isoflavonoid type, specifically rotenones. One of the most important glycosides present in plant is amorphine. The compound was used in the former U.S.S.R. as a cardio-sedative drug in nervous complaints, vegetative neurosis of the cardiovascular system and paroxysmal tachycardia [KADYROVA \& al. 1973a, KADYROVA \& al. 1973b].

This study focuses on the chemical and biological analysis of alcoholic extracts from Amorpha fruticosa fruits, leaves and branches, collected from Romania.

\section{Material and methods}

\section{Plant material}

The fruits, branches and leaves of Amorpha fruticosa were harvested in October from Pietrarie area (Iaşi, Romania). The plant material was authenticated by specialists from Department of Pharmaceutical Botany, "Grigore T. Popa" University of Medicine and Pharmacy Iasi, Romania, and the voucher specimens were deposited in the Department Herbarium. The plant material was dried at room temperature, under shade.

\section{Chemicals}

Gallic acid, 2,2-diphenyl-1-picrylhydrazyl (DPPH) were purchased from SigmaAldrich (Steinheim, Germany). Folin-Ciocalteu's phenol reagent, methanol, ethanol, acetic acid and hydrochloric acid, Mueller Hinton broth and agar were obtained from Merck (Darmstadt, Germany), while Sabouraud 4\% glucose agar was from Fluka Biochemika (Buchs, Switzerland). The antibiotics discs were purchased from Himedia (Mumbai, India).

Standards: caffeic acid, chlorogenic acid, $p$-coumaric acid, kaempferol, apigenin, rutoside, quercetin, quercitrin, isoquercitrin, fisetin, hyperoside, and myricetin from Sigma (Germany), ferulic acid, gentisic acid, sinapic acid, patuletin, and luteolin from Roth (Germany), and caftaric acid from Dalton (USA). Methanolic stock solutions $(100 \mathrm{~g} / \mathrm{mL})$ of the above standards were prepared and stored at $4{ }^{\circ} \mathrm{C}$, protected from daylight. Before being used as working solutions, they were appropriately diluted with double distilled water.

\section{Preparation of extracts}

$50 \mathrm{~g}$ of pulverized plant material (leaves, fruits and branches) were extracted by percolation with $70 \% \mathrm{v} / \mathrm{v}$ ethanol according to the $10^{\text {th }}$ edition of Romanian Pharmacopoeia (1993).

\section{HPLC apparatus and chromatographic conditions}

The analysis used an Agilent 1100 HPLC Series system, equipped with G1315A DAD detector and Agilent 1100 Ion Trap VL mass detector. The column used was Zorbax SB-C18 analytical column, with the following characteristics: $100 \mathrm{~mm}$ x $3.0 \mathrm{~mm}$ id, $3.5 \mu \mathrm{m}$ particle, maintained at $48{ }^{\circ} \mathrm{C}$. For preparation of the mobile phase was used a binary gradient made up of methanol:acetic acid $0.1 \%(\mathrm{v} / \mathrm{v})$. In the first 35 minutes, gradient elution started at $5 \%$ to $42 \%$ methanol, and in the next three minutes was isocratic elution with $42 \%$ methanol. 
UV detection and quantification of polyphenol compounds was achieved at $330 \mathrm{~nm}$ and $370 \mathrm{~nm}$ for flavonoids. Electrospray ionization (ESI) interface for mass detector was used and the analysis mode was multiple reaction monitoring (MRM) and single ion monitoring (SIM). We optimized conditions: negative ionization, ion source temperature 350 ${ }^{\circ} \mathrm{C}$, nebulizer nitrogen pressure at $60 \mathrm{psi}$, capillary voltage $+3000 \mathrm{~V}$, nitrogen gas with a flow rate of $12 / \mathrm{min}$.

The conditions of the methods like retention time, parameters of calibration curves, characteristic ions were described in our previous papers [IVĂNESCU \& al. 2010].

\section{Determination of total phenols}

The content of total phenolic compounds in branches, leaves and fruits extracts of Amorpha fruticosa was assessed by a variant described by Singleton of the Folin-Ciocalteu colorimetric method [LUNGU \& al. 2011]. The method is based on the reduction of FolinCiocalteu reagent to give a blue color, with visible spectrophotometric detection. For this purpose, for $2 \mathrm{~mL}$ of each extract in suitable dilution were added $10 \mathrm{~mL}$ of Folin-Ciocalteu reagent $(1: 10)$ and $8 \mathrm{~mL}$ solution of $7.5 \% \mathrm{Na}_{2} \mathrm{CO}_{3}$. The absorbance was measured at a wavelength of $760 \mathrm{~nm}$ after a reaction time of 2 hours at $20^{\circ} \mathrm{C}$, vs a blank consisting of water and reagent, using a Jasco V530 UV-VIS Spectrophotometer. The total concentration of phenolic compounds was calculated using the regression equation obtained from a standard curve prepared with gallic acid solutions in ranging concentrations $0-500 \mu \mathrm{g} / 100 \mathrm{~mL}$. The total content of phenolic compounds was expressed as gallic acid equivalents meaning milligrams of gallic acid per gram of the dried plant material.

\section{DPPH Radical Scavenging Activity Assay}

The assay of 2,2-diphenyl-1-picrylhydrazyl (DPPH) radical scavenging activity was carried out by the method of MALTERUD \& al. (1993). Each extract was dissolved and diluted in dimethylsulfoxide in different concentrations $(0.75 \mathrm{mg} / \mathrm{mL}$ and $1.25 \mathrm{mg} / \mathrm{mL}$ fruit extract, $1.5 \mathrm{mg} / \mathrm{mL}$ and $3 \mathrm{mg} / \mathrm{mL}$ leaves extract, $9 \mathrm{mg} / \mathrm{mL}$ and $18 \mathrm{mg} / \mathrm{mL}$ branches extract). Each dilution of extracts $(0.05 \mathrm{~mL})$ was added to $2.95 \mathrm{~mL}$ solution of DPPH in methanol $\left(\mathrm{A}_{517} \mathrm{~nm}=1.00 \pm 0.05\right)$ and mixed vigorously. The absorbance of DPPH radical solution was measured spectrophotometrically at $517 \mathrm{~nm}$ before $\left(\mathrm{A}_{0}\right)$ and 5 minutes after mixing $\left(\mathrm{A}_{1}\right)$. The inhibition of free radicals from DPPH as a percentage was calculated with the following formula:

DPPH radical scavenging activity $(\%)=100 \times\left(\mathrm{A}_{0}-\mathrm{A}_{1}\right) / \mathrm{A}_{0}$

For each sample the effective concentration $\left(\mathrm{EC}_{50}\right)$ was calculated. This value was defined as the concentration of 50\% DPPH radical scavenging activity. Quercetin was used as a positive control and all tests were carried out in triplicate.

\section{Microorganisms}

The antimicrobial activity was studied using Gram positive bacteria (Staphylococcus aureus ATCC 25923, Sarcina lutea ATCC 9341, Bacillus cereus ATCC 14579, Bacillus subtilis), Gram negative bacteria (Escherichia coli ATCC 25922) and pathogenic yeasts (Candida albicans ATCC 10231, Candida sake, Candida glabrata). All these strains were obtained from the Culture Collection of the Department of Microbiology, Faculty of Pharmacy, "Grigore T. Popa" University of Medicine and Pharmacy, Iasi, Romania. 


\section{Agar disc diffusion method}

Antimicrobial activity was evaluated by agar disc diffusion method according to described protocols [NCCLS, 2012]. Sterile stainless steel cylinders (50 mm internal diameter; $100 \mathrm{~mm}$ height) were applied on the agar surface in Petri plates. $100 \mu \mathrm{L}$ of each volatile oil sample were added to each cylinder. Commercial available discs containing ampicillin $(25 \mu \mathrm{g} / \mathrm{disc})$, chloramphenicol $(30 \mu \mathrm{g} / \mathrm{disc})$ and nystatin $(100 \mu \mathrm{g} / \mathrm{disc})$ were used. The plates were incubated at $37^{\circ} \mathrm{C}$ for $24 \mathrm{~h}$ (bacteria) and at $24{ }^{\circ} \mathrm{C}$ for $48 \mathrm{~h}$ (yeasts). After incubation the diameters of inhibition zones were measured.

\section{Statistical analysis}

All assays were carried out in triplicate. Results are expressed as means \pm SD. The $\mathrm{EC}_{50}$ values were calculated by linear interpolation between values above and below $50 \%$ activity.

\section{Results and discussions}

\section{Total phenolic content}

Table 1 shows the total phenolic content in Amorpha fruticosa extracts, determined by spectrophotometric method. The content of total phenolic compounds was highest in leaves extract followed by fruits extract and branches extract.

Table 1. Total phenolic content in Amorpha fruticosa extracts

\begin{tabular}{|c|c|c|c|}
\hline \multirow{3}{*}{$\begin{array}{l}\text { Total phenolic } \\
\text { content } \mathrm{mg} / \mathrm{g}\end{array}$} & \multicolumn{3}{|c|}{ Amorpha fruticosa extract } \\
\hline & branches & leaves & fruits \\
\hline & 14.08 & 159.5 & 122.10 \\
\hline
\end{tabular}

The total polyphenols in leaf extract determined in our study was higher than the one determined in an ethanolic extract $(54.7 \mathrm{mg}$ GAE/g dried plant) by HOVANET \& al. (2015). These results can be explained by the different harvest period (August vs. October), and also by the distinct environmental conditions.

\section{HPLC analysis of polyphenols}

Eighteen polyphenolic compounds have been investigated: one hydroxybenzoic acid, six cinnamic acid derivatives, four quercetin glycosides, and seven aglycones of flavonol and flavone type. The amounts of polyphenols found in Amorpha extracts are presented in Table 2, expressed in $\mathrm{mg} / \mathrm{g}$ dried plant material. The polyphenolic compounds are shown in order of their retention time. Quantification of constituents was performed using UV detection at $330 \mathrm{~nm}$ for phenol carboxylic acids and $370 \mathrm{~nm}$ for flavonoids. 
Bianca IVĂNESCU \& al.

Table 2. Polyphenol compounds in Amorpha fruticosa extracts (mg/g)

\begin{tabular}{|c|c|c|c|c|c|c|c|c|c|}
\hline \multirow{3}{*}{ Polyphenols } & \multicolumn{9}{|c|}{ Amorpha fruticosa extract } \\
\hline & \multicolumn{3}{|c|}{ branches } & \multicolumn{3}{|c|}{ leaves } & \multicolumn{3}{|c|}{ fruits } \\
\hline & UV & MS & $\begin{array}{l}\text { Conc. } \\
\mathrm{mg} / \mathrm{g}\end{array}$ & UV & MS & $\begin{array}{c}\text { Conc. } \\
\mathrm{mg} / \mathrm{g}\end{array}$ & UV & MS & $\begin{array}{l}\text { Conc. } \\
\mathrm{mg} / \mathrm{g}\end{array}$ \\
\hline Gentisic acid & - & $*$ & - & - & $*$ & - & - & $*$ & - \\
\hline Caffeic acid & - & $*$ & - & - & $*$ & - & - & $*$ & - \\
\hline Chlorogenic acid & - & $*$ & - & - & $*$ & - & - & $*$ & - \\
\hline p-coumaric acid & ** & $*$ & 0.0232 & $*$ & $*$ & - & $*$ & $*$ & 0.0557 \\
\hline Ferulic acid & $*$ & $*$ & 0.0081 & $*$ & $*$ & 0.0121 & $*$ & $*$ & 0.0233 \\
\hline Hyperoside & $*$ & $*$ & - & $*$ & $*$ & 0.2402 & $*$ & $*$ & 0.0122 \\
\hline Isoquercitrin & $*$ & $*$ & - & $*$ & $*$ & 9.4476 & $*$ & $*$ & 0.1765 \\
\hline Rutoside & $*$ & $*$ & 0.5931 & $*$ & $*$ & 11.8603 & $*$ & $*$ & 0.2754 \\
\hline Quercitrin & $*$ & $*$ & 0.0117 & $*$ & $*$ & 0.3139 & - & - & - \\
\hline Quercetin & $*$ & $*$ & 0.0089 & $*$ & $*$ & 0.0641 & - & - & - \\
\hline Luteolin & $*$ & $*$ & 0.0162 & $*$ & $*$ & 0.0093 & $*$ & $*$ & 0.0688 \\
\hline Kaempferol & - & - & - & $*$ & $*$ & 0.0202 & $*$ & $*$ & 0.1595 \\
\hline
\end{tabular}

*only MS qualitative determination was done; UV signal < LoQ (limit of quantification) or interferences/peak overlapping from other compounds does not allow the quantitative determination of these substances Not found: sinapic acid, caftaric acid, fisetin, patuletin, apigenin, myricetin

The results indicate the presence of ferulic acid, luteolin and rutoside in all samples in different concentrations. Gentisic acid, caffeic acid and chlorogenic acid could not be quantified in any of samples, but they were identified. Quercitrin and quercetin could not be founded in fruits extract and kaempferol in branches extract. Hyperoside and isoquercetrin from branches extract and p-coumaric acid from leaves extract were identified by UV and MS, but could not be determined quantitatively because the amount was below the limit of quantification. Rutoside was found in large quantities in all three extracts, and in leaves and fruits extracts was followed by isoquercitrin. The quantity of quercitrin and quercetin was higher in leaves extract than branches extract. Also, hyperoside and isoquercitrin were in higher quantities in leaves extract than fruits extract.

Our results correlated with those of CUI \& al. (2017) who also have isolated and identified rutin, trans-p-coumaric acid, quercetin, apigenin and other compounds in leaf extracts harvested in different periods of the year (May to August).

\section{Antioxidant activity}

The free radical scavenging activity of the three extracts was measured by the DPPH method. This method has been widely used to evaluate free radical scavenging ability of different plant extracts. DPPH is a free radical stable at room temperature that possesses a characteristic absorption at $517 \mathrm{~nm}$ (purple in colour). It is reduced in the presence of an antioxidant to yellow-coloured methanol solutions. Table 3 shows the $\mathrm{EC}_{50}$ values for the antioxidant activity of Amorpha fruticosa extracts. 
Table 3. DPPH radical scavenging activities $\left(\mathrm{EC}_{50}\right)$ of Amorpha fruticosa extracts

\begin{tabular}{cc}
\hline $\begin{array}{c}\text { Amorpha fruticos } \boldsymbol{a} \text { extracts/ } \\
\text { Positive control }\end{array}$ & $\mathbf{E C}_{\mathbf{5 0}}{ }^{\mathbf{a}}(\boldsymbol{\mu g} / \mathbf{m L})$ \\
\hline Leaves extract & $38.03 \pm 0.75$ \\
\hline Fruits extract & $18.8 \pm 0.2$ \\
\hline Branches extract & $221.16 \pm 1.7$ \\
\hline Quercetin & $2.2 \pm 0.0$ \\
\hline
\end{tabular}

The highest scavenging effect was observed in Amorpha fruticosa fruits extract $\left(\mathrm{EC}_{50}=18.80 \pm 0.20 \mu \mathrm{g} / \mathrm{mL}\right)$, followed by leaves extract $\left(\mathrm{EC}_{50}=38.03 \pm 0.75 \mu \mathrm{g} / \mathrm{mL}\right)$ and branches extract $\left(\mathrm{EC}_{50}=221.16 \pm 1.70 \mu \mathrm{g} / \mathrm{mL}\right)$. The $\mathrm{EC}_{50}$ value of quercetin was lower than those of Amorpha fruticosa extracts indicating higher DPPH scavenging activity. Quercetin is a known flavonol with high ability to scavenge free radicals. The presence of three hydroxyl groups, a 2,3-double bond and a 4-oxo function in the C-ring are important structural element for enhanced antioxidant activity [CAI \& al. 2006].

The antioxidant activity of the ethanolic extracts of Amorpha fruticosa has not been yet investigated. Recently, ZHELEVA-DIMITROVA \& al. (2013) reported that the 80\% methanol (v/v) extract of Amorpha fruticosa fruits showed a stronger scavenging activity on DPPH radicals $\left(\mathrm{EC}_{50}=9.83 \mu \mathrm{g} / \mathrm{mL}\right)$ than leaves extract $\left(\mathrm{EC}_{50}=11.23 \mu \mathrm{g} / \mathrm{mL}\right)$. Different antiradical activities of the same species can be explained by differences in plant extraction, method of analysis used and geographical origin of plant.

\section{Antimicrobial activity}

The antimicrobial activity of the extracts was tested against four Gram-positive bacteria (Staphylococcus aureus, Sarcina lutea, Bacillus cereus, Bacillus subtilis), two Gramnegative bacteria (Escherichia coli, Pseudomonas aeruginosa) and against three fungi (Candida albicans, Candida glabrata, Candida sake). The test was carried out by a disc diffusion method, using ampicillin, chloramphenicol and nystatin as positive control. The effects of ethanol extracts from branches, leaves and fruits of Amorpha fruticosa on the tested strains are shown in Table 4.

According to results, the fruit extract was active against all Gram positive bacteria with a diameter of inhibition zone ranging between 15 and $25 \mathrm{~mm}$. The branches and the leaves extracts showed similar activity against Staphylococcus aureus ATCC 25923 and Sarcina lutea ATCC 9341. No extract was active on the Gram negative strains and fungi.

Table 4. Antimicrobial activity of Amorpha fruticosa extracts

\begin{tabular}{llccccc}
\hline \multirow{2}{*}{ Microorganism } & \multicolumn{6}{c}{ Diameter of inhibition zone (mm) } \\
\cline { 2 - 7 } & $\begin{array}{c}\text { Branches } \\
\text { extract }\end{array}$ & $\begin{array}{c}\text { Leaves } \\
\text { extract }\end{array}$ & $\begin{array}{c}\text { Fruits } \\
\text { extract }\end{array}$ & $\begin{array}{c}\text { Ampicillin } \\
(25 \mu \mathrm{g} / \mathrm{disc})\end{array}$ & $\begin{array}{c}\text { Chloram } \\
\text { phenicol } \\
(30 \mu \mathrm{g} / \mathrm{disc})\end{array}$ & $\begin{array}{c}\text { Nystatin } \\
(100 \mu \mathrm{g} / \mathrm{disc})\end{array}$ \\
\hline Staphylococcus aureus ATCC 25923 & 16 & 21 & 19 & 26 & 24 & $\mathrm{nt}$ \\
\hline Sarcina lutea ATCC 9341 & 15 & 22 & 25 & 28 & 26 & $\mathrm{nt}$ \\
\hline Bacillus cereus ATCC & 0 & 0 & 16 & 0 & 21 & $\mathrm{nt}$ \\
\hline Bacillus subtilis & 0 & 0 & 17 & 26 & 29 & $\mathrm{nt}$ \\
\hline Escherichia coli ATCC 25922 & 0 & 0 & 0 & 21 & 29 & $\mathrm{nt}$ \\
\hline Pseudomonas aeruginosa ATCC 27853 & 0 & 0 & 0 & 0 & 16 & 18 \\
\hline Candida albicans ATCC 10231 & 0 & 0 & 0 & $\mathrm{nt}$ & $\mathrm{nt}$ & $\mathrm{nt}$ \\
\hline Candida glabrata ATCC MYA 2950 & 0 & 0 & 0 & $\mathrm{nt}$ & $\mathrm{nt}$ & 19 \\
\hline Candida sake & 0 & 0 & 0 & $\mathrm{nt}$ & $\mathrm{nt}$ & 20 \\
\hline
\end{tabular}

$$
\text { nt - not tested }
$$


For fruits, the results obtained in the antimicrobial test are similar to those reported by BORCHARDT \& al. (2008) for Amorpha fruticosa fruit and seeds harvested from the Mississippi river basin (USA). The 50\% methanol extract showed a $17 \mathrm{~mm}$ zone of inhibition against Staphylococcus aureus and demonstrated no effect on Escherichia coli, Pseudomonas aeruginosa and Candida albicans [BORCHARDT \& al. 2008].

For the leaf extract, our results can also be correlated with those of HOVANET \& al. (2015). They determined that the extract was active on Gram positive bacteria (Staphylococus aureus ATCC 6538 and Bacillus subtilis), inactive on some of Gram negative strains (Pseudomonas aeruginosa 13202, Escherichia coli ATCC 13202) and on some Candida strains. There are no reported results in literature for the antimicrobial activity of the branch extract.

\section{Conclusions}

The content of total polyphenolic compounds within extracts is correlated with their antioxidant and antimicrobial activity. Overall, fruits extract of Amorpha fruticosa proved to have a good DPPH scavenging effect. These results indicate that the ethanol extract of fruits may be a good source of natural antioxidants. In addition, the antimicrobial test showed that Gram positive bacteria are moderately sensitive to the action of Amorpha fruticosa extracts.

\section{Notes on contributors}

Bianca IVĂNESCU is an associate professor at Department of Pharmaceutical Botany, University of Medicine and Pharmacy "Gr. T. Popa" Iaşi, PhD. Her work focuses on pharmacological activities of medicinal plants, identification, extraction and isolation of natural compounds from plants.

Cristina LUNGU is an assistant at Department of Pharmaceutical Botany, University of Medicine and Pharmacy "Gr. T. Popa" Iasi, PhD with a special interest in the study of chemical and biological activities of plants.

Adina Catinca GRĂDINARU is an assistant at the discipline of Pharmaceutical Botany, University of Medicine and Pharmacy "Gr. T. Popa” Iaşi, with a PhD in Pharmacognosy, with specials interests in botany and pharmacognosy. Her work focuses on screening the antimicrobial potential of plant extracts, also on testing the interactions between plant extracts and classical antibiotics.

Laurian VLASE is a professor at the Department of Pharmaceutical Technology and Biopharmaceutics, "Iuliu Haţieganu" University of Medicine and Pharmacy, $\mathrm{PhD}$, with expertise in liquid chromatography, mass spectrometry, HPLC and a special interest in the analysis of natural compounds.

Cristina TUCHILUȘ is a professor at the Department of Microbiology, University of Medicine and Pharmacy "Gr. T. Popa" Iaşi, PhD. Her work focuses on testing the sensibility of pathogenic microorganisms to new antibiotics and screening the antimicrobial potential of plant extracts and compounds.

\section{References}

BORCHARDT J., WYSE D. L., SHEAFFER C. C., KAUPPI K. L., FULCHER R. G., EHLKE N. J., BIESBOER D. D. \& BEY R. F. 2008. Antioxidant and antimicrobial activity of seed from plants of the Mississippi river basin. Journal of Medicinal Plants Research. 2(4): 081-093.

CAI Y. Z., SUN M., XING J., LUO Q. \& CORKE H. 2006. Structure-radical scavenging activity relationships of phenolic compounds from traditional Chinese medicinal plants. Life Sciences. 78: 2872-2888. https://doi.org/10.1016/j.lfs.2005.11.004

CHO J. Y., KIM P. S., PARK J., YOO E. S., BAIK K. U., KIM Y. K. \& PARK M. H. 2000. Inhibitor of tumor necrosis factor-alpha production in lipopolysaccharide-stimulated RAW264.7 cells from Amorpha fruticosa. Journal of Ethnopharmacology. 70(2): 127-133. https://doi.org/10.1016/s0378-8741(99)00154-3

CUI X., GUO J., LAI C. S., PAN M. H., MA Z., GUO S., LIU Q., ZHANG L., HO C. T. \& BAI N. 2017. Analysis of bioactive constituents from the leaves of Amorpha fruticosa L. Journal of Food and Drug Analysis. 25: 992999. https://doi.org/10.1016/j.jfda.2016.10.006 
DE HAAN L. R., EHLKE N. J., SHAEFFER C. C., WYSE D. L. \& DE HAAN R. L. 2006. Evaluation of diversity among North American accessions of false indigo (Amorpha fruticosa L.) for forage and biomass. Genetic Resources and Crop Evolution. 53: 1463-1476. https://doi.org/10.1007/s10722-005-6845-6

DIAO Y. P., LI K. \& al. 2009. A new compound from the fruit of Amorpha fruticosa and activity against acetaminopheninduced hepatotoxicity. Chinese Chemical Letters. 20: 942-944.

HOVANET M. V., MARINAS I. C., DINU M., OPREAE., CHIFIRIUC M. C., STAVROPOULOU E. \& LAZĂR V. 2015. The phytotoxicity and antimicrobial activity of Amorpha fruticosa L. leaves extract. Romanian Biotechnological Letters. 20(4): 10670-10678.

IVĂNESCU B., VLASE L., CORCIOVĂ A. \& LAZĂR M. I. 2010. HPLC/DAD/MS study of polyphenols from Artemisia absinthium L., A. annua L. and A. vulgaris L. Chemistry of Natural Compounds. 46(3): 394-396.

KADYROVA F. R., SHAMSUTDINOV M. R. I. \& al. 1973a. Isolation of fruticine from Amorpha fruticosa seeds. Chemistry of Natural Compounds. 9: 114-115.

KADYROVA F. R., ZUBKOVA L. P. \& al. 1973b. Production control of fruticine. Chemistry of Natural Compounds. 9: 270-271.

KIM Y. S., RYU Y. B., CURTIS-LONG M. J., YUK H. J., CHO J. K., KIM J. Y., KIM K. D., LEE W. S. \& PARK K. H. 2011. Flavanones and rotenoids from the roots of Amorpha fruticosa L. that inhibit bacterial neuraminidase. Food and Chemical Toxicology. 49: 1849-1856. https://doi.org/10.1016/j.fct.2011.04.038

LEE H. J., KANG H. Y., KIM C. H., KIM H. S., KWON M. C., KIM S. M., SHIN I. S. \& LEE H. Y. 2006. Effect of new rotenoid glycoside from the fruits of Amorpha fruticosa LINNE on the growth of human immune cells. Cytotechnology. 52: 219-226. https://doi.org/10.1007/s10616-006-9040-5

LEE H. J., LEE O. K., KWON Y. H., CHOI D. H., KANG H. Y., LEE H. Y., PAIK K. H. \& LEE H. J. 2006. Isoflavone glycosides from the bark of Amorpha fruticosa. Chemistry of Natural Compounds. 42(4): 415-418. https://doi.org/10.1007/s10600-006-0169-4

LUNGU APETREI C., TUCHILUS C., APROTOSOAIE A. C., OPREA A., MALTERUD K. E. \& MIRON A. 2011. Chemical, antioxidant and antimicrobial investigations of Pinus cembra L. bark and needles. Molecules. 16(9): 7773-7788. https://doi.org/10.3390/molecules16097773

MALTERUD K. E., FARBROT T. L., HUSE A. E. \& SUND R. B. 1993. Antioxidant and radical scavenging effects of anthraquinones and anthrones. Pharmacology. 47: 77-85. https://doi.org/10.1159/000139846

PAPANASTASIS V. P., YIAKOULAKI M. D., DECANDIA M. \& DINI-PAPANASTASI O. 2008. Integrating woody species into livestock feeding in the Mediterranean areas of Europe. Animal Feed Science and Technology. 140: 1-17. https://doi.org/10.1016/j.anifeedsci.2007.03.012

SÎRBU C., OPREA A., SAMUIL C. \& TĂNASE C. 2012. Neophyte invasion in Moldavia (eastern Romania) in different habitat types. Folia Geobotanica. 47(2): 215-229. https://doi.org/10.1007/s12224-011-9112-y

ZHELEVA-DIMITROVA D. Z. 2013. Antioxidant and acetylcholinesterase inhibition properties of Amorpha fruticosa L. and Phytolacca americana L. Pharmacognosy Magazine. 9(34): 109-113. https://doi.org/10.4103/09731296.111251

*** Clinical and Laboratory Standards Institute. Methods for dilution antimicrobial susceptibility tests for bacteria that grow aerobically. 2012. Approved standard M07-A8 and Informational Supplement M100-S19. 2012. 29. National Committee for Clinical Laboratory Standards, Wayne, Pa.

*** Romanian Pharmacopoeia 10 ${ }^{\text {th }}$ edition. 1993. Bucuresti: Edit. Medicală, 921 pp.

\section{How to cite this article:}

IVĂNESCU B., LUNGU C., VLASE L., GRADINARU A. C. \& TUCHILUȘ C. 2019. HPLC analysis of phenolic compounds, antioxidant and antimicrobial activity of Amorpha fruticosa L. extracts. J. Plant Develop. 26: 77-84. https://doi.org/10.33628/jpd.2019.26.1.77 